\title{
ГЕОХІМІЧНИЙ БАР'СР ЯК ЗАСІБ ЗАХИСТУ НАВКОЛИШНЬОГО СЕРЕДОВИЩА ВІД ШКІДЛИВОГО ВПЛИВУ АВТОТРАНСПОРТУ Й АВТОЗАПРАВНИХ СТАНЦЙ
}

\section{Климчик О. М.}

\section{ВСТУП}

Одним 3 найсерйозніших факторів впливу на природне середовище будь-якої території є ii надмірна забрудненість викидами шкідливих речовин як стаціонарними, так і пересувними джерелами, до яких належать усі види автомобільного транспорту. В умовах зростання урбанізації особливу небезпеку для густонаселених територій становить саме автотранспорт, яким забезпечується більшість вантажних i пасажирських перевезень.

Автомобільний транспорт має важливе значення в загальній транспортній системі будь-якої країни. Він широко застосовується в усіх галузях народного господарства. Завдяки низці властивих йому особливостей автотранспорт, у порівнянні 3 іншими видами транспорту, є найбільш ефективним для використання, оскільки для нього характерна висока маневреність, що дає змогу зосереджувати транспортні засоби в необхідній кількості безпосередньо на місці утворення вантажів, іноді в найвіддаленіших і малодоступних пунктах; автономність, тобто мала залежність від постійних шляхів сполучення; висока швидкість перевезень, можливість використання в разі перевезення «від дверей до дверей» без додаткових перевантажень, перевезення на великі відстані швидкопсувних і термінових вантажів. Значна мобільність, можливість оперативно реагувати на зміни пасажиропотоків ставлять автотранспорт поза конкуренції в організації місцевих перевезень пасажирів. Крім того, цей вид транспорту вирізняють порівняно невеликі капіталовкладення в обладнання терміналів (навантажувально-розвантажувальних потужностей) i використання автошляхів загального користування. Тому в сучасних умовах розвитку суспільства зростання потреб у перевезенні вантажів у різних сферах економіки, надзвичайна мобільність людей зумовлює значне збільшення виробництва автотранспортних засобів (далі - АТЗ). Дані статистичної інформації свідчать, що світовий випуск автомобілів за останні 30 років зріс більше ніж удвічі ${ }^{1}$.

\footnotetext{
${ }^{1}$ Список стран по производству автотранспортных средств. URL : ttps://ru.qwe.wiki/wiki/List_of countries_by_motor_vehicle_production.
} 
Постійне збільшення кількості автомобілів підвищує мобільність населення, сприяє вирішенню загальнодержавних економічних потреб, поліпшує господарські зв'язки між різними територіально-адміністративними одиницями країни тощо. Разом із тим автомобільний транспорт ускладнює екологічну ситуацію, адже він належить як до найбільших споживачів матеріальних, земельних й енергетичних ресурсів, так і до найбільших забруднювачів довкілля. Його інтенсивна робота $є$ однією з основних причин порушення екологічної рівноваги навколишнього середовища.

Крім того, зі збільшенням автомобільного парку зростає потреба в збільшенні кількості автозаправних станцій (далі - АЗС). На таких станціях проводиться заправляння автомобілів пальним, дозаправляння й доливання мастила й води, підкачування шин стисненим повітрям, а також забезпечення рухомого транспортного складу автоексплуатаційними матеріалами. 3 метою поліпшення обслуговування та розширення можливостей у наданні послуг власникам автотранспорту в Україні й окремих іiі регіонах щорічно з'являються все нові й нові АЗС. Однак АЗС, навіть найсучасніші, також чинять потужний техногенний вплив на довкілля, що проявляється у вигляді відведення територій під забудову, вирубування лісозахисних смуг, створення підземних резервуарів, а також у вигляді розливання під час заправки й неналежного зберігання нафтопродуктів тощо.

Постійне зростання кількості АТЗ, АЗС і мережі автомобільних доріг спричинює розбалансування екологічного стану природних екосистем. Тому оцінка впливу АТЗ й АЗС на стан довкілля наразі $є$ досить актуальною, оскільки вона $\epsilon$ основою для розроблення заходів зі зниження рівнів техногенного тиску на навколишне природне середовище.

\section{1. Транспортні засоби й автозаправні станції як чинники негативного впливу на довкілля}

Транспортний комплекс $є$ важливою складовою економіки будь-якої держави, оскільки він задовольняє як загальнодержавні потреби, так і потреби населення в перевезеннях, поліпшує господарські зв'язки між різними територіально-адміністративними одиницями країни. Наразі перевезення пасажирів і вантажів $є$ не тільки місцевим, а й міжміським та міжнародним. За статистичними даними, упродовж 2015-2019 рр. в Україні автотранспортом здійснено понад 70\% вантажних і більш як 40\% пасажирських перевезень від загальної кількості перевезень усіма видами транспорту (рис. 1, рис. 2$)^{2}$.

\footnotetext{
${ }^{2}$ Транспорт і зв'язок України за 2018 р. : стат. збірник / Державна служба статистики України / за ред. I. Петренко. URL : http://www.ukrstat.gov.ua/druk/publicat/kat_u/2019/zb/08/zb_tr2018pdf.pdf (дата звернення 29.06.2020).
} 


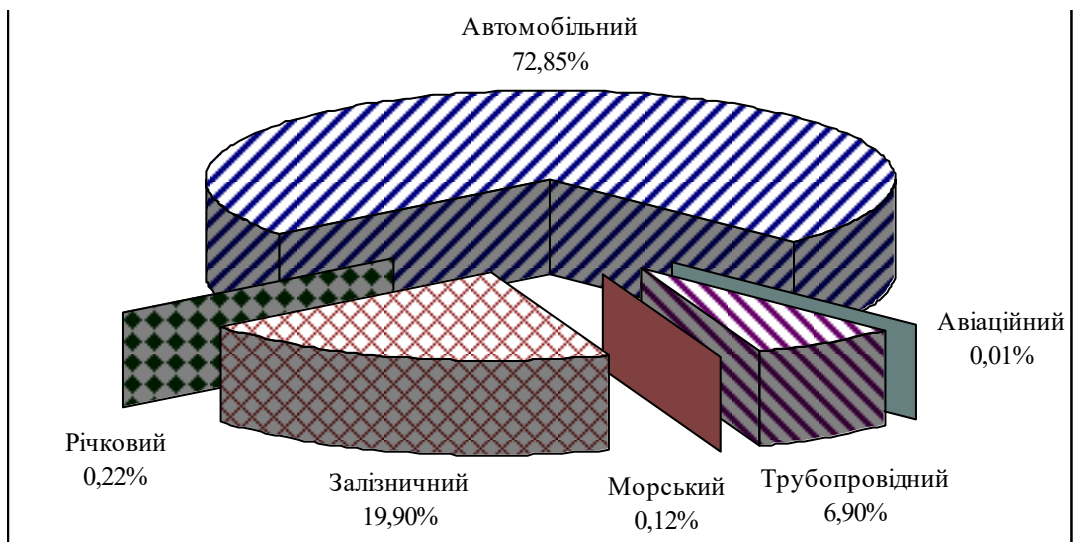

Рис. 1. Питома вага окремих видів транспорту в перевезенні вантажів у 2018 р.

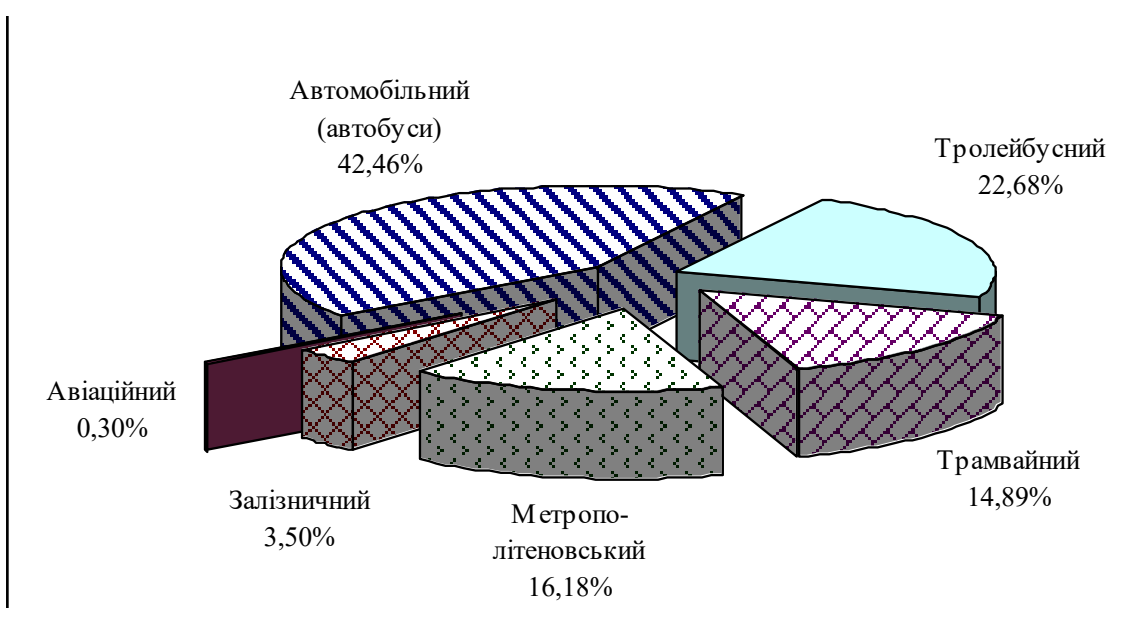

Рис. 2. Розподіл окремих видів транспорту в загальному перевезенні пасажирів у 2018 p.

3 іншого боку, функціонування будь-якого виду АТЗ супроводжується потужним негативним впливом на всі складники довкілля - атмосферу, воду, грунти, рослинний i тваринний світ, а також на здоров'я населення. Детально ці питання розглянуті в роботі Г. І. Архіпової, I. С. Ткачука та Є. I. Глушкова «Аналіз впливу відпрацьованих автомобільних газів...» ${ }^{3}$.

Поодинокий автомобіль, що пересувається по дорозі, не чинить помітного впливу на навколишнє середовище й екосистеми. Інша справа сукупність АТЗ, що рухаються в складі транспортних потоків автомобільними дорогами. А. Г. Говорун, В. Ф. Скорченко, М. М. Худолій стверджують, що вплив на довкілля визначається не тільки технічними характеристиками автомобіля чи дороги, але й інтенсивністю, швидкістю

\footnotetext{
${ }^{3}$ Архіпова Г. І., Ткачук I. С., Глушков С. І. Аналіз впливу відпрацьованих автомобільних газів на стан атмосферного повітря в густонаселених районах. Вісник Національного авіаційного університету. 2009. № 1. C. 78-83. DOI: 10.18372/2306-1472.38.1667.
} 
руху АТЗ, складом транспортного потоку, характером покриття дорожньої мережі тощо ${ }^{4}$.

Перетворення хімічної енергії палива на роботу 3 переміщення вантажів і пасажирів пов'язане 3 утворенням токсичних і шкідливих речовин з відпрацьованими газами двигунів, продуктів зносу шин й антифрикційних матеріалів, а також споживання у великих обсягах моторного палива й мастил. В результаті досліджень Данилка В. К. установлено, що лише один легковий автомобіль вітчизняного виробництва щорічно споживає від 1000 до 1500 кг пального й до 9-13 кг моторного мастила 5 .

Забруднення повітря, пов'язане 3 роботою агрегатів автомобіля, має три основних джерела: система випуску двигуна, система змащення й вентиляції картера, система живлення паливом. Найбільша частина шкідливих речовин, що виділяються двигуном автомобіля, припадає на частку відпрацьованих газів, що $\epsilon$ продуктом неповного згоряння використовуваного палива, у складі яких містяться різноманітні хімічні сполуки, у тому числі небезпечні для здоров'я людини та шкідливі для довкілля. Науково-лабораторні аналізи відпрацьованих газів автомобілів засвідчують, що в їхньому складі міститься майже 200 компонентів (Архіпова Г. І. та інші).

У кожному конкретному випадку кількість відпрацьованих автомобільних газів і їхній склад залежать від типу, моделі АТЗ, режиму роботи двигуна, його технічного стану й часу перебування в експлуатації, виду застосовуваного палива, присадок тощо. Характерно, що їхня кількість збільшується за малих швидкостей руху автомобіля, коротких відстаней, розбігу й зупинок. Якщо на автомобілі встановлено карбюраторний двигун, то у складі його вихлопних газів серед нетоксичних речовин найбільшу питому вагу має нітроген (74-77\%), карбон (II) оксид (5-12\%), пара води $(3,3-5 \%)$. Майже така сама кількість нетоксичних речовин викидається дизельними двигунами. Якщо порівняти токсичні речовини, то різниця в кількості їхніх викидів залежно від виду двигуна досить суттєва. Викиди містять також сажу

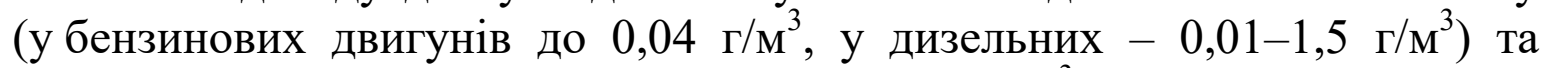
бенз(а)пірен (у бензинових - до 0,00002 $г / \mathrm{m}^{3}$, у дизельних - до 0,00001 г/м $\left.{ }^{3}\right)$ (Архіпова Г. І., Данилко В. К.).

За даними Луканина В. Н. і Трофименко Ю. В., у складі відпрацьованих газів автомобіля найбільшу питому вагу за об'ємом мають: сполуки плюмбуму (до 60\%), бенз(а)пірен (до 25\%), карбон (IV) оксид $(5-12 \%)$ і карбон (II) оксид $(0,1-10 \%)$, неспалені вуглеводні $(0,2-3 \%)$, нітроген (IV) оксид (до 0,6 \%), альдегіди (до 0,2\%) і сажа. У абсолютних

\footnotetext{
${ }^{4}$ Говорун А. Г., Скорченко В. Ф., Худолій М. М. Транспорт і навколишнє середовище. Київ, 1992. $144 \mathrm{c}$.

${ }^{5}$ Данилко В. К. Статистика екології автотранспорту. Житомир, 2001. 172 с.
} 
величинах на 1000 л пального карбюраторний двигун викидає 3 вихлопними й картерними газами: 200 кг карбон (II) оксиду, 25 кг вуглеводнів, 20 кг нітрогену, 1 кг сульфурвмісних сполук, один кг сажі ${ }^{6}$.

За даними Архіпової Г. I, по країнах СС у викидах більшості шкідливих речовин найбільшу питому вагу мають легкові автомобілі 3 бензиновими двигунами. Так, на них припадає $80 \%$ викидів карбон (IV) оксиду та плюмбуму, майже половина оксидів нітрогену й летких органічних сполук. Водночас транспортні засоби малої та навіть великої вантажопідйомності шкідливих речовин викидають у повітря значно менше, ніж легкові автомобілі.

Дослідженнями науковців географічного факультету Московського державного університету ім. М. В. Ломоносова Н. С. Кошелевої, Д. В. Власова, І. Д. Корлякова, Н. С. Касимова також установлено, що до $35 \%$ від загальних викидів автотранспорту обумовлюються дорожніми умовами. Зона впливу автодороги поширюється на відстань до 3 км від узбіччя проїжджої частини залежно від інтенсивності дорожнього руху, його складу, а також від метеорологічних, кліматичних і топографічних умов місцевості ${ }^{7}$.

Крім того, склад забруднюючих речовин різних видів АТЗ характеризує питома вага певних викидів. Ці дані свідчать, що найбільшу питому вагу у викидах більшості шкідливих речовин мають легкові автомобілі з бензиновими двигунами. Так, їхня частка становить $80 \%$ викидів окису карбону й плюмбуму, у межах половини - окисів нітрогену й летких органічних сполук. Водночас транспортні засоби малої й навіть великої вантажопідйомності викидають у повітря значно менше шкідливих речовин, ніж легкові автомобілі, про що зазначено в роботі «Автомобиль и окружающая среда» П. М. Канило та інших ${ }^{8}$.

Відомо, що рух АТЗ у складі переповнених транспортних потоків на дорожній мережі відрізняється від руху поодинокого АТЗ за відсутності перешкод рухові, як під час проведення випробувань 3 оцінювання токсичності й паливної економічності. Пов'язані з цим зміни умов руху (швидкості, прискорень), які досліджував М. В. Михно у своїй праці «Влияние состава транспортного потока...», викликають зміни швидкісних режимів роботи двигунів, значень викидів шкідливих речовин і витрат пального АТЗ 3 .

Питомі (на одиницю пробігу - пробігові, г/кг) викиди шкідливих речовин, витрата пального встановлюються в окремих фазах руху

\footnotetext{
${ }^{6}$ Луканин В. Н., Трофименко Ю. В. Промышленно-транспортная экология. Москва, 2001. 273 с.

${ }^{7}$ Kosheleva N., Vlasov D., Korlyakov I., Kasimov N. Effect of build development on contamination of urban soils with heavy metals. PNRPU. Applied ecology. Urban development. 2018. № 1. Pp. 36-55. DOI: 10.15593/2409-5125/2018.01.03.

${ }^{8}$ Канило П. М., Бей И. С., Ровенский А. И. Автомобиль и окружающая среда. Харьков, 2000. 304 с.

9 Михно М. В. Влияние состава транспортного потока на экологические показатели. Автошляховик Украӥни. 1999. № 3. С. 18.
} 
автомобіля: під час розгону, руху з постійною швидкістю, сповільнення та в режимі холостого ходу. Ці питання розкрив Ю. Г. Якубовський ще у $1979 \mathrm{p.}^{10}$. Миттєві й інтегральні (за часом) значення швидкості, прискорення автомобіля, витрата пального, викиди шкідливих речовин в окремих фазах руху оцінюються на основі таких вихідних даних, як-от: вантажно-швидкісні режими роботи двигуна й концентрація компонентів відпрацьованих газів $\left(\mathrm{CO}, \mathrm{C}_{\mathrm{x}} \mathrm{H}_{\mathrm{y}}, \mathrm{NO}_{\mathrm{X}}, \mathrm{CO}_{2}\right.$, твердих частинок).

Для оцінки витрати пального в режимі холостого ходу бензинових АТЗ можна використовувати формулу (Ю. Г. Якубовський):

$$
G_{T}=0,1079+19683,45 \cdot \Pi-3046397,75 \cdot \Pi^{2}, R^{2}=0,9047,
$$

де $\Pi$ - комплексний показник, що відображає одночасно рівень форсування двигуна за тепловим, динамічним навантаженням i матеріаломісткість конструкцій $\left[\kappa \Gamma \cdot \pi /\left(\mathrm{\kappa BT}^{2} \cdot \mathrm{xB}^{-1}\right)\right]$. Значення П становить: для бензинових легкових АТЗ $(0,2-0,3) \cdot 10^{-4}$, бензинових автобусів $(0,4-1,3) \cdot 10^{-4}$, вантажних АТЗ і автобусів 3 дизелями - $(2,0-4,1) \cdot 10^{-4}$.

Згідно з розрахунками Ю. Г. Якубовського в бензинових АТЗ під час розгону суттєво зростають викиди $\mathrm{CO}$ і $\mathrm{NO}_{\mathrm{x}}$. Витрата палива та викиди $\mathrm{C}_{\mathrm{x}} \mathrm{H}_{\mathrm{y}}$ також зростають у 3,5-7,9 раза. Під час сповільнення значення питомих викидів знижуються у 3-10 разів (рис. 3).

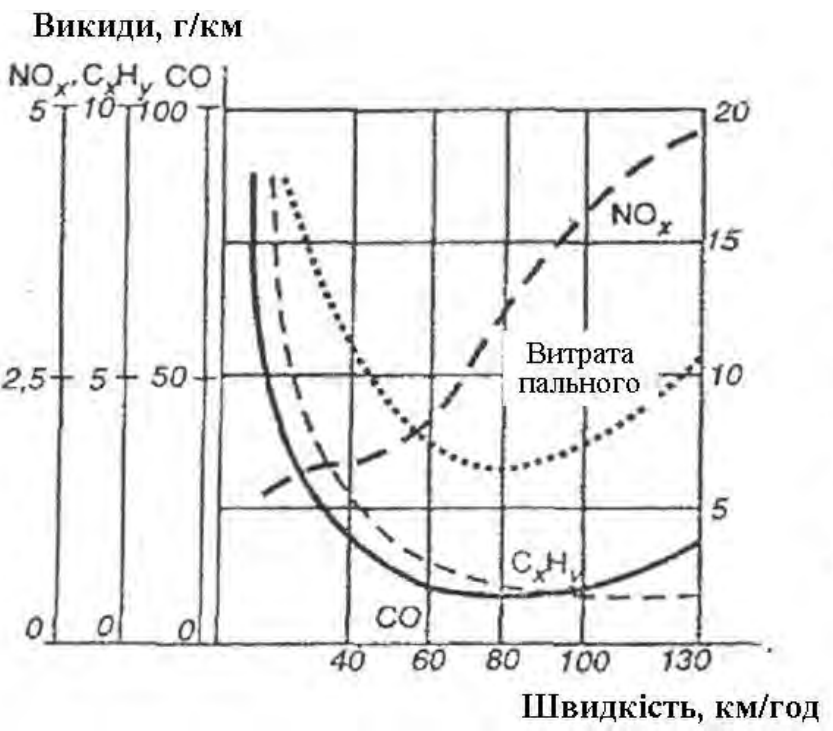

Рис. 3. Залежність питомих викидів легкових АТЗ від швидкості руху (Ю. Г. Якубовський, 1979 р.)

У відпрацьованих газах дизельних АТЗ зростають викиди твердих частинок і витрата палива. Викиди газових АТЗ також істотно нижчі

10 Якубовский Ю. Автомобильный транспорт и защита окружающей среды. Москва, 1979. 198 с. 
порівняно 3 бензиновими. За використання газодизельного циклу помітно зростають викиди $\mathrm{CO}$ та $\mathrm{C}_{\mathrm{x}} \mathrm{H}_{\mathrm{y}}$, але зменшується кількість викидів $\mathrm{NO}_{\mathrm{x}}$ і твердих частинок. Кількість викидів $\mathrm{CO}$ вантажних АТЗ й автобусів 3 бензиновими двигунами внутрішнього згоряння у 5,4-6,5 раза більша, ніж у дизельних аналогів. Однак в останніх більше викидів $\mathrm{NO}_{\mathrm{x}}$ (у 2,7 й 1,9 раза відповідно), твердих частинок $\mathrm{i}_{\mathrm{SO}_{2}}$ (М. В. Михно).

Наразі основним видом пального, що використовується автотранспортом, є бензин. Загалом у світі понад 90\% автомобілів мають бензинові двигуни. Останнім часом на автотранспорті широко стали застосовувати природний газ. Найбільшу частку машин, що працюють на цьому виді пального, становлять пасажирські автобуси $11 \%$. Загалом же по країнах світу налічується близько 1 млн автомобілів, двигуни яких працюють на скрапленому природному газі (Г. І. Архіпова, В. К. Данилко).

Отже, автотранспорт - це основне джерело емісії в атмосферу складної суміші хімічних сполук, склад яких залежить не тільки від виду палива, типу двигуна й умов його експлуатації. На величину питомих викидів шкідливих речовин впливають як категорія, вік і технічний стан АТЗ, так і умови їхнього руху.

3 метою поліпшення обслуговування й розширення можливостей у наданні послуг власникам автотранспорту в регіоні щорічно з'являються все нові й нові АЗС, призначенням яких $€$ забезпечення рухомого транспортного складу автоексплуатаційними матеріалами. На таких станціях проводиться заправлення автомобілів пальним, дозаправлення й доливання мастила й води, а також підкачування шин стисненим повітрям.

Відповідно до вимог природоохоронного законодавства, зокрема Закону України «Про планування і забудову територій», під час проєктування й розміщення АЗС мають передбачатися заходи зі зниження викидів і скидів забруднюючих речовин шляхом використання сучасного обладнання, систем уловлювання, знезараження й утилізації шкідливих викидів, скидів а також парів нафтопродуктів ${ }^{11}$. Такі заходи мають забезпечити дотримання гранично допустимих концентрацій (далі - ГДК) забруднюючих речовин в атмосферному повітрі, у стічних водах й у грунтах, прилеглих до територій АЗС, про що зазначено в Державних будівельних нормах «Містобудування...»"

Вибір типу АЗС для конкретного місця розташування проводять залежно від потужності й технологічних рішень 3 урахуванням

\footnotetext{
${ }^{11}$ Про планування і забудову територій : Закон України від 20 квітня 2000 p. № 1699-IП. URL : http://search.ligazakon.ua/__doc2.nsf/link1/T001699.html (дата звернення 05.07.2020).

12 Містобудування. Планування і забудова населених пунктів. ДБН Б.2.2-1-01. URL http://www.dnaop.com/html/34154/doc-ДБН_Б.2.4-2-94.
} 
містобудівних обмежень $\mathrm{i}$ вимог чинного природоохоронного законодавства. АЗС, за умови дотримання санітарно-гігієнічних, екологічних, протипожежних та інших нормативних вимог, можуть проєктуватися також як автозаправні комплекси (далі - АЗК) 3 приміщеннями й окремими об'єктами сервісного обслуговування водіїв і транспортних засобів: для роздрібної торгівлі, швидкого харчування, миття й технічного обслуговування автомобілів (рис. 4).

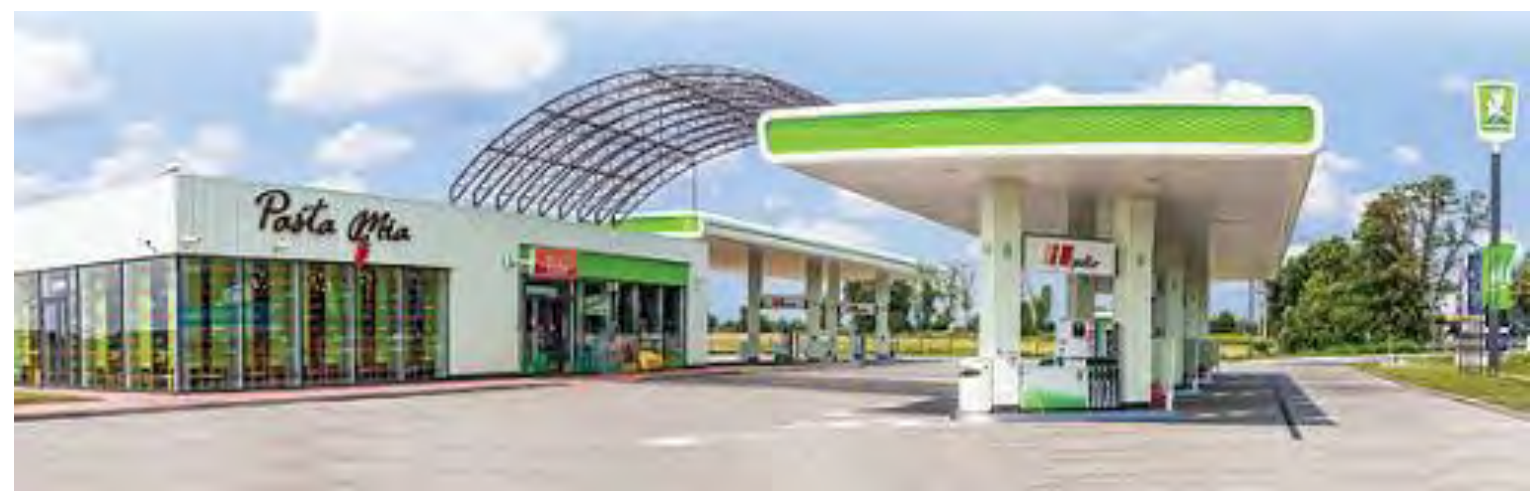

Рис. 4. Сучасний АЗК

Наразі будівництво АЗС відбувається хаотично, нерідко з порушенням чинних нормативів. На сьогодні мережа АЗС і автомобільних доріг, а також об'єкти транспортної інфраструктури чинять негативний вплив на довкілля на значній площі.

Наслідки впливу автотранспортних потоків i мережі АЗС на навколишнє середовище викладені в праці В. Н. Іванова та В. К. Сторчевуса «Экология и автомобилизация» ${ }^{13}$. Науковці зазначають, що цей вплив полягає в таких чинниках, як-от:

- забруднення атмосфери, водних об'єктів та земель, зміна хімічного складу грунтів та мікрофлори, утворення виробничих відходів, сміття тощо;

- споживання природних ресурсів - атмосферного повітря, яке необхідне для перебігу робочих процесів у двигунах внутрішнього згоряння (далі - ДВЗ) АТЗ; нафтопродуктів та природного газу, які $є$ паливом для ДВЗ; води для систем охолодження ДВЗ і миття транспортних засобів, виробничих та побутових потреб підприємств транспорту; земельних ресурсів, відчужених під будівництво автомобільних доріг, АЗС й інших об'єктів транспортної інфраструктури;

- виділення теплоти в довкілля під час роботи ДВЗ й установок, у яких спалюють паливо в транспортному виробництві;

- створення високих рівнів шуму й вібрації;

\footnotetext{
${ }^{13}$ Иванов В. Н., Сторчевус В. К. Экология и автомобилизация. 2-е изд., перераб. и доп. Киев, 1990. $128 \mathrm{c}$.
} 
- травмування й загибель людей i тварин, спричинення значних матеріальних збитків внаслідок аварій і катастроф;

- порушення грунтово-рослинного покриву, зменшення врожайності сільськогосподарських культур тощо.

Таким чином, джерелами шкідливого впливу на навколишнє середовище $є$ як автотранспортні засоби, так і сама АЗС як комплекс інженерно-технічних споруд. Вилучення територій під забудову, вирубування лісозахисних смуг, створення підземних резервуарів тощо призводить до руйнування природних екосистем. АТЗ, які обслуговує заправна станція, є джерелами негативного впливу на довкілля: це й викиди вихлопних газів, створення високих рівнів шуму й вібрації, виділення теплоти в довкілля під час роботи двигунів внутрішнього згоряння, виливання мастила, гальмівної рідини й таке інше.

Вплив на навколишнє середовище дорожньої мережі як сукупності інженерних споруджень виявляється поступово. Однак ця група впливу небезпечна своїми наслідками, оскільки постійне зростання кількості АТЗ, мережі АЗС й автомобільних доріг спричинює погіршення екологічного стану довкілля й деградацію природних екосистем.

\section{2. Геохімічний бар'єр як засіб захисту навколишнього середовища}

Найчутливішим індикатором змін ландшафтно-геохімічних умов, що відбуваються внаслідок такого техногенного навантаження, є верхня частина літогенної основи ландшафтів, як зазначає Л. Л. Малишева у фундаментальній праці «Ландшафтно-геохімічна оцінка...»14. Ландшафтно-геохімічні умови визначають рівень й інтенсивність забруднення різних компонентів довкілля та здатність їх до самоочищення. Причому, за твердженням Н. М. Цвєткової та Є. О. Тагунової в статті «Геохімічні бар'єри в розподілі мангану...», поведінка полютантів в урбанізованому середовищі визначається не лише розміщенням джерел забруднення. Помітний вплив чинять рельєф, структура забудови i метеорологічні фактори, що визначають розсіювальну й накопичувальну здатність атмосфери ${ }^{15}$. У цих умовах, де $\epsilon$ безліч антропогенних джерел у вигляді промислових підприємств, автомагістралей і мережі АЗС, розрахунок поширення забруднень від техногенних джерел стає дуже складною задачею. Вони формують досить високий рівень вмісту забруднених аерозолів у повітрі, який сильно варіює, оскільки частинки різного розміру переносяться на різну відстань. Хімічний склад частинок, що випадають 3 атмосфери в умовах

\footnotetext{
${ }^{14}$ Малишева Л. Л. Ландшафтно-геохімічна оцінка екологічного стану території : монографія. Київ, 1997. 264 c.

15 Цвєткова Н. М., Тагунова Є. О. Геохімічні бар'єри в розподілі мангану в едафотопах Присамар'я Дніпровського. Visn. Dnipropetr. Univ. Ser. Biol. Ekol. 2015. 23 (1). DOI:10.15421/011501. 
урбанізованих територій, досліджували Н. С. Кошелева, Н. С. Касимов, Д. В. Власов. Хімічний склад частинок сильно різниться залежно від їхнього розміру та походження. Опади складаються з грубих частинок PM10 діаметром < 10 мкм, дрібних - PM2.5 (<2,5 мкм) і PM1 (<1 мкм), а також дуже дрібних частинок РМ0.1 $(<0,1 \text { мкм })^{16}$.

Забруднюючі речовини осідають 3 атмосфери на поверхню грунтів і нагромаджуються в них, змінюючи морфологічні та фізико-хімічні властивості верхніх горизонтів. Під час еколого-гідрохімічного моніторингу грунтів, що акумулюють полютанти, зокрема важкі метали (далі - BM), такі як $\mathrm{Cu}, \mathrm{Zn}, \mathrm{Pb}, \mathrm{Cd}, \mathrm{Cr}, \mathrm{Ni}, \mathrm{Co}$, протягом багаторічного періоду, слід застосовувати багатовимірний статистичний аналіз грунтово-геохімічних даних, вважають Н. С. Кошелева, Д. В. Власов, І. Д. Корляков, Н. С. Касимов, сутність якого розкрита у статті «Влияние застройки на загрязнение городских почв тяжелыми металлами» ${ }^{17}$.

Темпи накопичення ВМ залежать від міцності зв'язків з грунтовими компонентами, зокрема оксидами й гідроксидами $\mathrm{Fe}$ i Mn, глинистими мінералами, органічною речовиною, що обумовлено хімічними властивостями елемента, формами сполук, які надходять $з$ техногенних джерел, і геохімічною обстановкою, тобто окислювально-відновними та кислотно-лужними умовами. Форми знаходження хімічних елементів $\mathrm{i}$ сукупність антропогенних чинників та ландшафтних умов впливають на міграційну здатність ВМ і визначають швидкість їх накопичення в грунтах (Н. Е. Кошелева, Н. С. Касимов «Факторы накопления тяжелых металлов...»).

Наразі для запобігання міграції забруднювачів і захисту грунтів від накопичення ВМ традиційно використовують такі геохімічні бар'єри (далі - ГХБ): окислювальний, сульфідний, сорбційний гідроксидний i сорбційний глинистий, лужний (гідролітичний i карбонатний), відновлювальний. Детальну характеристику матеріалів, що використовуються для створення ГХБ, наведено в статті Богуславського А. Е. та Кривенка А. П. «К вопросу использования геохимических барьеров...» ${ }^{18}$.

Термін «геохімічний бар'єр» введено А. І. Перельманом. Починаючи 3 1961 р. він створював основи класифікації ГХБ, яка відбиває сутність

\footnotetext{
${ }^{16}$ Кошелева Н. Е., Касимов Н. С., Власов Д. В. Факторы накопления тяжелых металлов и металлоидов на геохимических барьерах в городских почвах. Почвоведение. 2015. № 5. С. 536-553. DOI: $10.7868 / \mathrm{S} 0032180 \mathrm{X} 15050032$.

${ }^{17}$ Kosheleva N., Vlasov D., Korlyakov I., Kasimov N. Effect of build development on contamination of urban soils with heavy metals. PNRPU. Applied ecology. Urban development. 2018. № 1. Pp. 36-55. DOI: 10.15593/2409-5125/2018.01.03.

18 Богуславский А. Е., Кривенко А. П. К вопросу использования геохимических барьеров для предотвращения миграции паров ртути. Сибирский экологический журнал. 6 (2010). С. 843-850.
} 
вчення про них. А. І. Перельман визначає ГХБ як ділянку земної кори, де на короткій відстані відбувається різке зменшення інтенсивності міграції хімічних елементів $\mathrm{i}$, як наслідок, їх накопичення ${ }^{19}$.

Визначення терміну «бар'єр» стосовно грунтів і ландшафтів, їхня типологія, функціональні особливості й екологічне значення ГХБ детально розглянуто в одній зі статей М. А. Глазовської. У статті дано загальне визначення терміну «бар'єр» стосовно грунтів і ландшафтів «як перешкода на шляху руху грунтових розчинів і завислих твердих частинок різного розміру - мулистих, пилуватих, піщаних» ${ }^{20}$.

Згідно з сучасними уявленнями Н. С. Касимова та С. Н. Борисенко, які розвинули вчення про геохімічні бар'єри в роботі «Становление и развитие ученья о геохимических барьерах», ГХБ - це «відкрита, нерівноважна, динамічна система, що самоорганізовується, з безліччю чинників, які обумовлюють осадження елементів» ${ }^{21}$.

Найбільш детальну оцінку функціональної ролі ГХБ у міграції й трансформації забруднювачів, їх представлення як форми самоорганізації природних систем, деталізацію й уточнення самого поняття «геохімічний бар'єр надано в роботах А. П. Хаустова «Геохимические барьеры с позиций синергетики (семантический анализ)» та «Геохимические барьеры как форма самоорганизации естественных геосистем» ${ }^{22}$. А. П. Хаустов розглядає ГХБ «як компоненти геохімічних систем, що самоорганізовуються, у яких відбувається активізація фізико-хімічних процесів, що призводить до трансформації атомно-молекулярних структур, хімічних асоціацій й окремих хімічних елементів під дією активних середовищ (процесів)» ${ }^{23}$.

Як правило, у природних умовах завжди має місце не один, а декілька ГХБ. Досвід роботи Лабораторії геології техногенних процесів Природничо-наукового інституту показав можливість використання геохімічних бар'єрів у різних ситуаціях (Л. Л. Малишева «Ландшафтноекологічна оцінка...»). Наразі на практиці їх активно застосовують у технологіях очищення й захисту грунтів, підземних і поверхневих вод $\mathrm{i}$ геологічного середовища в цілому (А. П. Хаустов). Водночас створюються нові техногенні бар'єри, які не мають природних аналогів.

\footnotetext{
${ }^{19}$ Перельман А. И. Геохимия. Москва, 1989. 423 с.

${ }^{20}$ Глазовская М. А. Геохимические барьеры в почвах: типология, функциональные особенности и экологическое значение. Геохимия ландшафтов и география почв. Москва, 2012. С. 26-44.

${ }^{21}$ Касимов Н. С., Борисенко Е. Н. Становление и развитие ученья о геохимических барьерах / Геохимические барьеры в зоне гипергенеза. Москва, 2002. С. 6-37.

${ }_{22}$ Хаустов А. П. Геохимические барьеры с позиций синергетики (семантический анализ) / Геохимия ландшафтов (к 100-летию А. И. Перельмана) : доклад Всероссийской. научной конференции, Москва, 18-20 октября 2016 г. Москва, 2016. С. 64-67.

23 Хаустов А. П. Геохимические барьеры как форма самоорганизации естественных геосистем. Вестник Российскогой университета дружбы народов. Серия «Экология и безопасность жизнедеятельности». 2017. Т. 25. № 3. С. 396-413. DOI 10.22363/2313-2310-2017-25-3-396-413. 
Місткість штучних ГХБ, як правило, набагато більша, ніж у природних аналогів, що є важливим чинником прискореного накопичення ВМ.

Сутність методів захисту навколишнього середовища від забруднення за допомогою ГХБ полягає в переведенні забруднюючих компонентів у малорухомі форми. Водночас можливо як використання наявних природних геохімічних бар'єрів, так і створення штучних. Як матеріал для створення бар'єрів, залежно від складу забруднювачів, можуть застосовуватися природні утворення (грунти, гірські породи тощо) або інші речовини, наприклад виробничі відходи.

\section{3. Практичне використання геохімічних бар'срів}

\section{3 метою зменшення шкідливого впливу функціонування АЗС}

Розроблення методів поліпшення екологічної ситуації шляхом зменшення шкідливої дії автомобільного транспорту й функціонування АЗС до останнього часу проводилося переважно на основі удосконалення покриття, застосування універсального матеріалу, додаткового озеленення. На сьогодні для захисту навколишнього середовища, як зазначено у роботах А. С. Богуславського, Н. С. Касимова, Є. Н. Борисенко, А. П. Хаустова, В. А. Алєксєєнко та інших науковців, намітилася тенденція використання геохімічних методів, зокрема геохімічних бар'єрів ${ }^{24}$.

Розроблення способів мінімізації шкідливого впливу функціонування АЗС на навколишнє середовище на основі використання природних матеріалів, таких як глина, вапняк, торф та інші, для створення штучних ГХБ натепер $\epsilon$ актуальною задачею. Найбільш перспективними матеріалами $є$ модифіковані торфи 3 підвищеним вмістом гумінових кислот, оскільки вони можуть сприяти зниженню техногенного впливу потенційно небезпечних речовин: гумінові кислоти утворюють міцні сполуки 3 іонами металів, а отже, можуть використовуватися як потужний геохімічний бар'єр (А. Е. Богуславський, А. П. Кривенко).

Шкідливі й токсичні речовини продуктів роботи АТЗ та функціонування АЗС виділяються в навколишне природне середовище. Вони осідають на поверхні грунту, на листі дерев, трав'янистих рослинах тощо. А далі, після випадіння атмосферних опадів, поверхневим стоком виносяться за територію АЗС, просочуються в підземні горизонти й досягають підземних вод.

Для прикладу розглянемо міграцію певної забруднюючої речовини в підземних водах. Підземні води являють собою складне рухоме середовище, як зазначено у праці М. М. Костюченка та В. С. Шабатина «Гідрогеологія та інженерна геологія» ${ }^{25}$. Міграція речовини відбувається

\footnotetext{
${ }^{24}$ Алексеенко В. А., Алексеенко Л. П. Геохимические барьеры. Москва, 2003. 144 с.

${ }^{25}$ Костюченко М. М., Шабатин В. С. Гідрогеологія та інженерна геологія. Київ, 2005. 144 с.
} 
переважно внаслідок конвекції, тобто переміщення речовини разом із водною фазою. За повільної швидкості потоку збільшується роль дифузії - міграції речовини завдяки наявності градієнтів концентрації. В реальному діапазоні швидкостей фільтрації підземних вод перенесення маси здійснюється головним чином шляхом конвекції, тобто разом із потоком рідини. Середня дійсна швидкість потоку $v$ визначається рівнянням:

$$
v=k \cdot i / n, \mathrm{M} / \mathrm{c},
$$

де $k$ - коефіцієнт фільтрації, $i$ - напірний градієнт, $n$ - активна пористість.

У процесі міграції відбувається дифузійне й фільтраційне розсіювання речовини, тобто його дисперсія. Фільтраційна дисперсія обумовлена розгалуженням елементарних струменів води в результаті неоднорідності поля швидкостей потоку усередині порового простору (мікродисперсія) та неоднорідності пор у водовмісних породах (макродисперсія). Таким чином, під час міграції речовини в підземних водах утворюється ареал іiі розсіювання зі зменшенням концентрацій до його меж.

Крім дисперсії, міграція речовини в підземних водах супроводжується хімічними, біохімічними й фізико-хімічними процесами, направленими на приведення в рівноважний стан системи «вода - порода». У разі потрапляння в підземні води забруднюючих речовин сукупність перерахованих процесів узагальнюється поняттям «самоочищення». Самоочищення підземних вод від неорганічних речовин відбувається, як правило, внаслідок осадження компонентів розчину на геохімічних бар'єрах (А. П. Хаустов та інші).

3 позиції самоочищення підземних вод найбільш ефективними $\epsilon$ глинисті бар'єри для елементів зі змінною валентністю та сорбційні для більшості елементів, які містяться у воді в мікрокількостях. Сорбційний глинистий бар'єр обумовлений наявністю негативного заряду на поверхні глинистих мінералів. У результаті катіонного обміну тут можуть осаджуватися $\mathrm{Li}, \mathrm{Be}, \mathrm{Zn}, \mathrm{Cu}, \mathrm{Cd}, \mathrm{Pb}, \mathrm{Hg}, \mathrm{Co}, \mathrm{Ni}, \mathrm{Tl}$ тощо (А. С. Богуславський, А. П. Кривенко).

Для захисту підземних і поверхневих вод від забруднення продуктами функціонування АТЗ й АЗС пропонується використання комплексного, багатошарового екрана-бар'єра. Конструкція екрана складається з трьох шарів (рис. 5).

Верхній шар потужністю 0,1 м створюється 3 місцевої глини 3 додаванням гіпсу. Він затримує частинки важких металів (кислий бар'єр $E$ ). Середній шар потужністю 0,1 м виготовлений із суміші торфу 3 місцевими глинами. Цей шар виконує основну функцію перехоплення забруднювачів - зв'язування металів у сульфіди в анаеробних 
відновлювальних умовах (відновлювальний сульфідний бар'єр $B$ ). Нижній шар складається 3 місцевих глин і $є$ допоміжним сорбційним екраном (сорбційний бар'єр $G$ ).

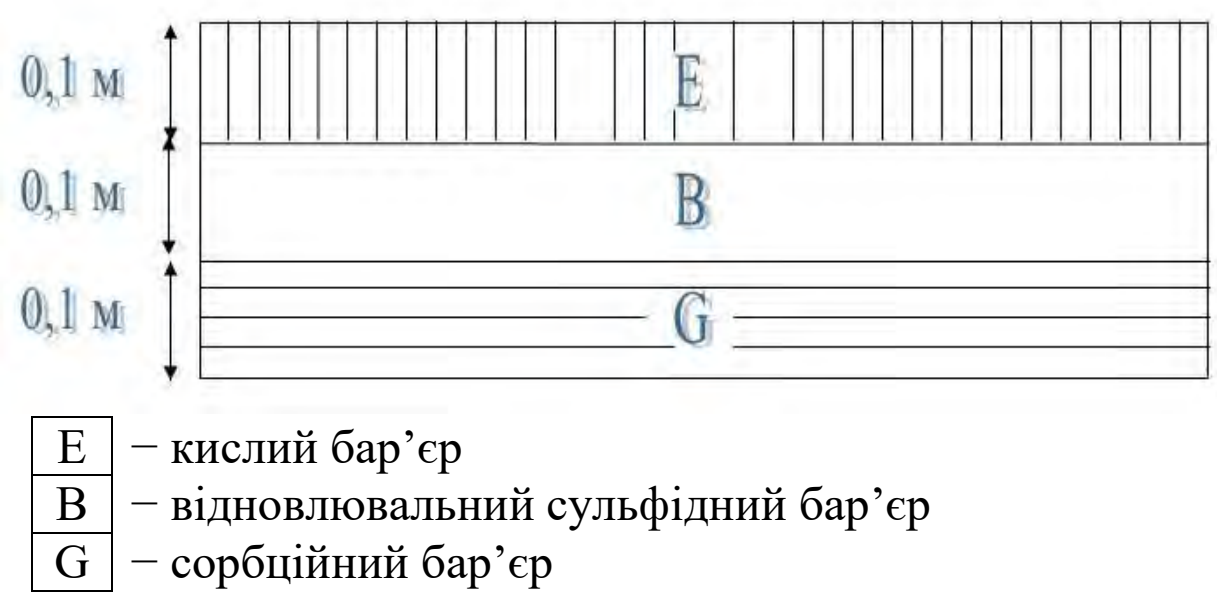

Рис. 5. Схема комплексного екрана-бар'єра

Роль верхнього й нижнього шарів глини в структурі екрана полягає також у зменшенні й розсіюванні фільтраційного навантаження на територію, прилеглу до АЗС. Менша потужність верхнього шару глини забезпечує фільтраційне затримування розчинів у середньому шарі. Залежно від літологічного складу грунтів і гідрогеологічних умов величину шарів екрана можна коригувати. Тобто, якщо грунти на території АЗС представлені піщаними породами, що сприяє підвищенню швидкості фільтрації від 1-5 до 15-20 м за добу й більше, то величину шарів екрана доцільно збільшити.

Застосування штучного геохімічного бар'єра запропонованої конструкції забезпечує захист територій, прилеглих до АЗС, від надходження забруднювачів. Також це $\epsilon$ економічно доцільним, оскільки використовуються місцеві, достатньо дешеві матеріали, а отже, влаштування геохімічних бар'єрів не вимагає значних грошових вкладень.

Наразі на ділянці Житомир - Київ автотраси Е-40 збудовано 33 АЗС переважно середньої категорії потужності 3 підземним розміщенням резервуарів. Аналізуючи структуру й розміщення таких АЗС на цій ділянці слід відмітити, що вони не завжди відповідають встановленим нормам. Тобто така кількість АЗС чинить вагоме техногенне навантаження на навколишнє природне середовище. Слід зазначити, що основне скупчення АЗС спостерігається в зонах, приналежних до урбанізованих територій, а саме поблизу міст Житомир і Київ.

За результатами досліджень, які проводилися на АЗС поблизу села Калинівка, що розташоване поряд 3 автотрасою Е-40 на ділянці 
Житомир - Київ на відстані 84 км від Житомира, встановлено, що час перебування кожного автомобіля на автозаправній станції становить у середньому п'ять хвилин. Як правило, протягом цього часу двигун автомобіля працює в режимі холостого ходу й середнє споживання пального становить: легковим автомобілем - 0,6 л, вантажним автомобілем - 1 л. В результаті споживання пального утворюються вихлопні гази двигунів внутрішнього згоряння, до складу яких входять азот $(\mathrm{N})$, пара води $\left(\mathrm{H}_{2} \mathrm{O}\right)$, вуглекислий газ (двоокис вуглецю $\left.\mathrm{CO}_{2}\right)$, окис вуглецю $(\mathrm{CO})$, окис азоту $\left(\mathrm{NO}_{2}\right)$, вуглеводні $\left(\mathrm{C}_{\mathrm{m}} \mathrm{H}_{\mathrm{n}}\right)$, альдегіди, сірчаний газ, сажа $(\mathrm{C})$ та бенз(а)пірен, свинець $(\mathrm{Pb})$. За добу така АЗС обслуговує в середньому 180 автомобілів, з них 130 легкових і 50 вантажних.

Одними з найтоксичніших із перерахованих забруднюючих речовин $\epsilon$ $\mathrm{BM}$, a саме свинець $(\mathrm{Pb})$. Для визначення середньодобових $\mathrm{i}$ середньорічних обсягів викидів Рb згідно 3 «Методикою розрахунку викидів шкідливих речовин в атмосферу автомобільним транспортом...» ${ }^{26}$ використовуються значення усереднених питомих викидів шкідливих речовин з одиниці використаного пального:

$$
W_{P b}=V_{n} \cdot \gamma, \mathrm{\kappa} \Gamma
$$

де $V_{n}$ - кількість спожитого пального одним автомобілем, т; $\gamma-$ значення питомих викидів, кг/т.

Зокрема, значення усереднених питомих викидів $\mathrm{Pb} \quad 3 \quad 1 \quad \mathrm{~T}$ використаного пального становлять: для легкових автомобілів - 0,5 кг; для вантажних - 0,23 кг. Результати розрахунків середньодобових i середньорічних обсягів викидів $\mathrm{Pb}$, які утворюються в результаті функціонування такої АЗС, наведено в табл. 1.

Як зазначено, шкідливі й токсичні речовини продуктів роботи автотранспорту й функціонування АЗС виділяються в навколишне природне середовище, накопичуються на поверхні грунту, на листі дерев, трав'янистих рослинах тощо. Внаслідок випадіння атмосферних опадів осаджені полютанти поверхневим стоком виносяться за територію АЗС, просочуються в підземні горизонти й досягають підземних вод. Швидкість їхньої міграції й обсяги накопичення залежать від рельєфу й гідрогеологічних умов певної ділянки.

Для захисту територій, прилеглих до АЗС, від забруднення шкідливими викидами слід використовувати багатошаровий екранбар'єр (рис. 6). Дані для розрахунку багатошарового екрана-бар'єра наведено в табл. 2.

\footnotetext{
${ }^{26}$ Методика розрахунку викидів шкідливих речовин в атмосферу автомобільним транспортом : затв. Наказом Міністерства статистики України від 3 березня 1992 р. № 03/1-9/8 та наказом Міністерства охорони навколишнього природного середовища України від 6 березня 1992 р. № 5/2-7177. Київ, 1992.8 с.
} 
Таблиця 1

Обсяги споживання пального й обсяги викидів $\mathrm{Pb}$ по АЗС «Калинівка»

\begin{tabular}{|c|c|c|c|c|c|c|}
\hline \multirow[t]{2}{*}{ Вид транспорту } & \multicolumn{2}{|c|}{$\begin{array}{c}\text { Обсяги } \\
\text { споживання } \\
\text { бензину } \\
\end{array}$} & \multicolumn{2}{|c|}{$\begin{array}{c}\text { Обсяги } \\
\text { споживання } \\
\text { бензину } \\
\end{array}$} & \multirow{2}{*}{$\begin{array}{c}\text { Питомі } \\
\text { викиди } \\
\text { свинцю, } \\
\text { кг/т }\end{array}$} & \multirow{2}{*}{$\begin{array}{c}\text { Обсяг } \\
\text { викидів } \\
\text { свинцю, } \\
\text { т/рік }\end{array}$} \\
\hline & л/добу & л/рік & кг/добу & кг/рік & & \\
\hline $\begin{array}{l}\text { Легкові автомобілі, } \\
\text { всього }\end{array}$ & 78 & 28470 & 57,72 & 21067,8 & 0,5 & 10,54 \\
\hline $\begin{array}{l}\text { Вантажні автомобілі, } \\
\text { всього }\end{array}$ & 50 & 18250 & 37 & 13505 & 0,23 & 3,11 \\
\hline Разом & 128 & 46720 & 94,72 & 34572,8 & - & 13,65 \\
\hline
\end{tabular}

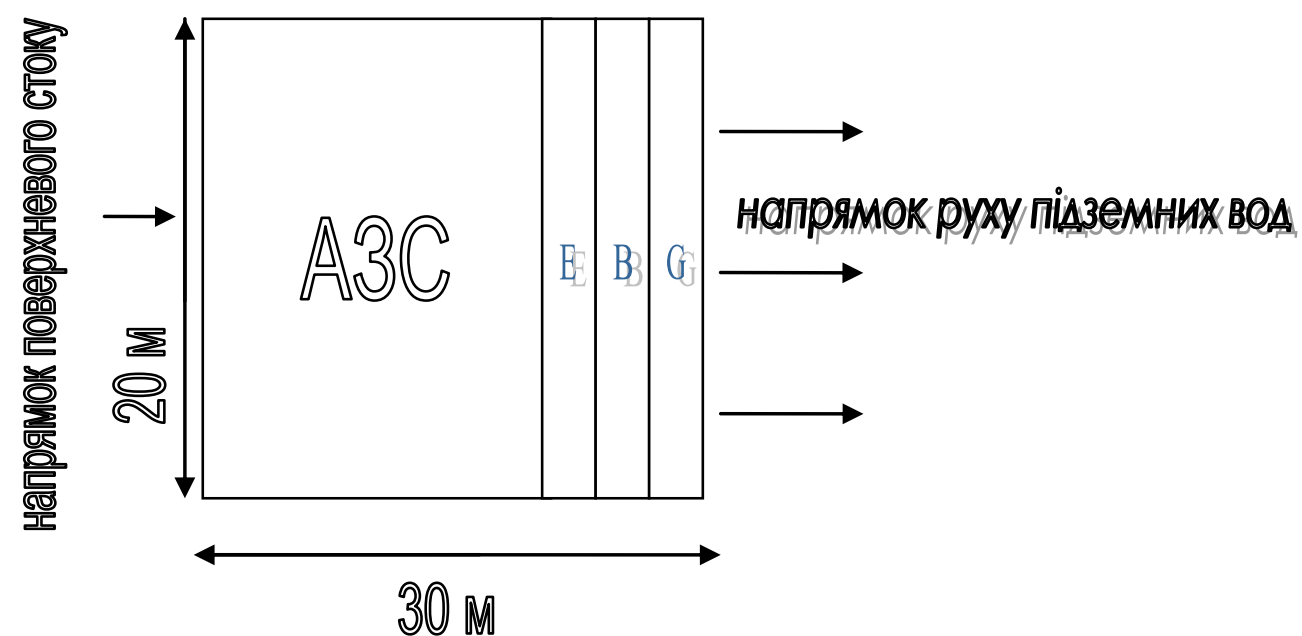

Рис. 6. Схема розміщення багатошарового екрана-бар'сра на території A3C

Для визначення геологічних і гідрогеологічних умов досліджуваної ділянки були проведені інженерно-геологічні вишукування, за яких визначено водні й фізико-механічні властивості грунтів.

Таблиця 2

Основні характеристики шарів геохімічного бар'єра

\begin{tabular}{|c|c|c|c|}
\hline \multirow[b]{2}{*}{$\begin{array}{c}\text { Водно-фізичні } \\
\text { характеристики грунтів }\end{array}$} & \multicolumn{3}{|c|}{ Грунти шарів геохімічного бар’єра } \\
\hline & $\begin{array}{c}\text { Глина } 3 \\
\text { гіпсом }\end{array}$ & $\begin{array}{l}\text { Глина } 3 \\
\text { торфом }\end{array}$ & $\begin{array}{c}\text { Глина } \\
\text { напівтверда }\end{array}$ \\
\hline Коефіцієнт фільтрації $k_{\phi}, \mathrm{M} / \mathrm{c}$ & $1 \cdot 10^{-7}$ & $1 \cdot 10^{-3}$ & $1 \cdot 10^{-9}$ \\
\hline Коефіцієнт пористості, $\varepsilon$ & 0,347 & 0,384 & 0,685 \\
\hline Щільність грунту, $\rho, \mathrm{T} / \mathrm{M}^{3}$ & 2,63 & 2,35 & 2,67 \\
\hline
\end{tabular}


Підземні води виявлено на глибині 3,5 м від поверхні землі. Похил ділянки $i$ становить 0,0143 . У геологічному відношенні за фільтраційними властивостями ділянка належить до категорії достатньо складних. 3 огляду на те, що на даній ділянці переважають піщані грунти, то згідно лінійного закону фільтрації Дарсі (2) поява забруднень, які надходять разом із підземними водами за територію ділянки, відбудеться достатньо швидко, оскільки піски мають значний коефіцієнт фільтрації (до 100 м/добу).

За даними Державного комітету з гідрометеорології середньорічна норма опадів становить 530 мм. Тоді на територію АЗС випадає $318 \mathrm{~m}^{3}$ опадів. Середньорічну витрату води, яка проходить через цей бар'єр, розраховуємо за формулою (М. М. Костюченко, В. С. Шабатін):

$$
Q=V_{\text {оп }} / T, \mathrm{M}^{3} / \mathrm{c} \text {, }
$$

де $V_{\text {on }}-$ середньорічний об'єм опадів на території АЗС, м³ $T$ - кількість секунд у році, с.

Тоді $Q$ становитиме $0,1 \cdot 10^{-5} \mathrm{~m}^{3} / \mathrm{c}$.

Для визначення об'єму екрана та його параметрів розраховуємо площу екрана $F$, крізь яку фільтруватимуться підземні води, забруднені шкідливими викидами, за формулою:

$$
F=Q / v_{\phi}, \mathrm{M}^{3},
$$

де $Q$ - середньорічна витрата води, ${ }^{3} / \mathrm{c} ; v_{\phi}$ - швидкість фільтрації, м/с.

Запропонований геохімічний бар'єр складається 3 трьох шарів. Верхній шар $E$ створюється 3 місцевої глини 3 додаванням гіпсу. Середній шар $B$ виготовлено $з$ суміші торфу 3 місцевими глинами. Нижній шар $G$ складається з місцевих глин і $є$ допоміжним сорбційним екраном. Оскільки найгірші фільтраційні властивості притаманні останньому шару 3 глини напівтвердої (коефіцієнт фільтрації $k_{\phi}$ становить $10^{-9} \mathrm{M} / \mathrm{c}$ ), то розрахунки проводимо для цих умов фільтрації.

Швидкість фільтрації згідно з законом фільтрації Дарсі дорівнюватиме: $v_{\phi}=0,02 \cdot 10^{-6} \mathrm{~m} / \mathrm{c}$. Тоді потрібна площа екрана становитиме $50 \mathrm{~m}^{2}$. Відповідно, глибина екрана - 1,6 м.

Встановлено, що 100 кг екрана такої конструкції може утримувати й перетворювати 4,7 кг свинцю 27 . Оскільки величина викидів на досліджуваній ділянці становить 13,65 т/рік, то нам потрібен екран масою 290,4 т.

Загальний об'єм екрана розраховуємо як суму об'ємів окремих шарів:

$$
V_{\text {заг }}=\sum V_{i}, \mathrm{M}^{3},
$$

${ }^{27}$ Алексеенко В. А., Алексеенко Л. П. Геохимические барьеры. Москва, 2003. 144 с. 
де

$$
V_{i}=m / \rho_{i}, \mathrm{M}^{3}
$$

де $m$ - маса відповідного шару екрана, т; $\rho_{i}-$ густина відповідного грунту, т/ $\mathbf{M}^{3}$.

Згідно 3 формулою (7) об'єми окремих шарів становитимуть: $V_{1}=36,8 \mathrm{~m}^{3} ; V_{2}=41,2 \mathrm{~m}^{3} ; V_{3}=36,3 \mathrm{~m}^{3}$. Тоді загальний об'єм екрана становитиме: $V_{\text {заг }}=114,3 \mathrm{~m}^{3}$.

Потужність кожного шару геохімічного бар'єра розраховуємо за формулою:

$$
H_{i}=V_{i} / F, \mathbf{M} \text {. }
$$

Отримуємо: $H_{\mathrm{E}}=0,74 \mathrm{м} ; H_{\mathrm{B}}=0,82 \mathrm{~m} ; H_{\mathrm{G}}=0,73 \mathrm{м}$.

Таким чином, пропонований геохімічний бар'єр складається 3 трьох шарів. Перший шар $E$, потужністю 0,74 м, створюється 3 місцевої глини 3 додаванням гіпсу. Другий шар $B$, потужністю 0,82 м, виготовлений iз суміші торфу з місцевими глинами. Третій шар $G$, потужністю 0,73 м, складається 3 місцевих глин і $є$ допоміжним сорбційним екраном. Загальна вага екрана - 290,4 т, а загальний об'єм - 114,3 м³.

Оскільки геохімічний екран-бар'єр має певний строк експлуатації ${ }^{28}, 3$ метою його встановлення необхідно проводити спостереження двічі на квартал. Це здійснюється за допомогою свердловини, яка розташована нижче АЗС за напрямком руху підземних вод на відстані 35 м від АЗС. Після втрати фільтраційних і сорбційних властивостей екран не зможе втримувати й фільтрувати шкідливі речовини, тому вода в спостережній свердловині буде забрудненою, що свідчитиме про необхідність заміни екрана.

Отже, для забезпечення захисту довкілля від негативного впливу внаслідок функціонування АТЗ й АЗС необхідно облаштувати екранування ділянок дороги обабіч АЗС штучними геохімічними бар'єрами, тобто зонами різкого зменшення міграційної здатності хімічних елементів сумарною довжиною 7,2 км. Сумарна довжина екранованих ділянок дороги становитиме лише 6\% від загальної довжини траси на ділянці Житомир - Київ.

\section{ВИСНОВКИ}

1. Вплив на навколишнє середовище дорожньо-транспортної мережі як сукупності інженерних споруд, й АТЗ виявляється поступово, однак він є небезпечним за своїми наслідками. Постійне зростання мережі АЗС й автомобільних доріг загального користування викликає деградацію природних екосистем. Поширеним i досить об’ємним видом

${ }^{28}$ Алексеенко В. А., Алексеенко Л. П. Геохимические барьеры. Москва, 2003. 144 с. 
забруднення автотранспортом навколишнього природного середовища $\epsilon$ розлиті під час заправлення й неналежного зберігання й відпрацювання нафтопродукти, а також викиди шкідливих речовин і важкі метали.

2. На ділянці автомобільної траси Е-40 Житомир - Київ, яка $є$ основним автотранспортним коридором країни в напрямку захід - схід, зосереджено понад $40 \%$ автомобільних перевезень широтного географічного напрямку країни.

3. За результатами моніторингових досліджень установлено, що кількість автозаправних станцій автомагістралі Е-40 на ділянці Житомир - Київ становить 33 одиниці. Проаналізувавши магістральношляхову структуру цієї автомагістралі, ми з'ясували, що основне скупчення АЗС - у зонах, приналежних до урбанізованих територій.

4. 3 метою поліпшення екологічного стану навколишнього природного середовища запропоновано виконати екранування ділянок доріг, прилеглих до АЗС, штучними геохімічними бар'єрами у вигляді екранівбар'єрів, які складаються з трьох шарів: перший шар, потужністю 0,74 м, створюється із місцевої глини 3 додаванням гіпсу; другий шар, потужністю 0,82 м, виготовляється із суміші торфу 3 місцевими глинами; третій шар, потужністю 0,73 м, складається 3 місцевих глин. Дія такого екрана грунтується на сорбційних властивостях глинистих грунтів i полягає у зменшенні та розсіюванні фільтраційного навантаження на територію, прилеглу до АЗС.

5. Застосування геохімічного бар'єра у вигляді багатошарового екрана як засобу захисту від забруднення довкілля дасть змогу знизити екологоекономічні збитки від забруднення до мінімальних величин і призведе до поліпшення екологічного стану територій, прилеглих до АЗС.

\section{АНОТАЦІЯ}

Автомобільний транспорт у суспільному житті відіграє надзвичайно важливу роль. Від стану розвитку, організації та ступеня використання автотранспортного й дорожнього комплексу значною мірою залежить прогрес і загальний стан економіки кожної країни, іiї міжнародний престиж.

Разом із тим автомобільно-дорожній комплекс негативно впливає на навколишнє середовище, що набуває останнім часом глобального характеру. Найголовнішим фактором забруднення автотранспортом довкілля $\epsilon$ забруднення атмосферного повітря вихлопними газами автомобілів, парами нафтопродуктів під час заправлення й пилом, що здіймається від руху автомобілів. Автомобільний транспорт, як у містах, так і на автомагістралях, постачає велику кількість шкідливих викидів і таким чином негативно впливає на екологічний стан навколишнього середовища. Слід зазначити, що, на відміну від промислових 
підприємств, викид яких концентрується в певній зоні, автомобіль поширює продукти неповного згоряння пального практично по всій території, причому безпосередньо у приземному шарі повітря, звідки утруднено їх розсіювання.

3 метою покращення обслуговування й розширення можливостей у наданні послуг власникам автотранспорту в регіоні щорічно з'являються все нові й нові АЗС, які призначені для забезпечення рухомого транспортного складу автоексплуатаційними матеріалами.

Наразі геохімічні бар'єри є активними практичними технологіями очищення й захисту грунтів, підземних і поверхневих вод та геологічного середовища в цілому. Для запобігання міграції забруднювачів і захисту грунтів від накопичення ВМ традиційно використовують ГХБ різних типів: окислювальний, відновлювальний, сорбційний, сульфідний, лужний.

Для забезпечення захисту довкілля від негативного впливу внаслідок функціонування АТЗ та АЗС необхідно облаштувати екранування ділянок автомагістралі обабіч АЗС штучними геохімічними бар'єрами, тобто зонами різкого зменшення міграційної здатності хімічних елементів.

\section{ЛIТЕРАТУРА}

1. Алексеенко В. А., Алексеенко Л. П. Геохимические барьеры. Москва, 2003. 144 с.

2. Архіпова Г. І., Ткачук I. С., Глушков С. I. Аналіз впливу відпрацьованих автомобільних газів на стан атмосферного повітря в густонаселених районах. Вісник Національного авіаиійного університету. 2009. № 1. С. 78-83. DOI: 10.18372/2306-1472.38.1667.

3. Богуславский А. Е., Кривенко А. П. К вопросу использования геохимических барьеров для предотвращения миграции паров ртути. Сибирский экологический журнал, 6 (2010). С. 843-850.

4. Глазовская М. А. Геохимические барьеры в почвах: типология, функциональные особенности и экологическое значение. Геохимия ландшафтов и география почв. 100 лет со дня рождения М. А. Глазовской / под ред. Н. С. Касимова, М. И. Герасимовой. Москва, 2012. С. 26-44.

5. Говорун А. Г., Скорченко В. Ф., Худолій М. М. Транспорт і навколишне середовище. Київ, 1992. 144 с.

6. Данилко В.К. Статистика екології автотранспорту. Житомир, 2001. $172 \mathrm{c}$.

7. Иванов В. Н., Сторчевус В. К. Экология и автомобилизация : 2-е изд., перераб. и доп. Киев, 1990. 128 с.

8. Канило П. М., Бей И. С., Ровенский А. И. Автомобиль и окружающая среда. Харьков, 2000. 304 с. 
9. Касимов Н. С., Борисенко Е. Н. Становление и развитие ученья о геохимических барьерах. Геохимические барьеры в зоне гипергенеза. Москва, 2002. С. 6-37.

10. Костюченко М. М., Шабатин В. С. Гідрогеологія та інженерна геологія. Київ, 2005. 144 с.

11. Кошелева Н. Е., Касимов Н. С., Власов Д. В. Факторы накопления тяжелых металлов и металлоидов на геохимических барьерах в городских почвах. Почвоведение. 2015. № 5. С. 536-553. DOI: $10.7868 / \mathrm{S} 0032180 \mathrm{X} 15050032$.

12. Луканин В. Н., Трофименко Ю. В. Промышленно-транспортная экология. Москва, 2001. 273 с.

13. Малишева Л.Л. Ландшафтно-геохімічна оцінка екологічного стану території : монографія. Київ, 1997. 264 с.

14. Методика розрахунку викиду шкідливих речовин в атмосферу автомобільним транспортом : затверджено наказом Міністерства статистики України від 3 березня 1992 р. № 03/1-9/8 і наказом Міністерства охорони навколишнього природного середовища України від 6 березня 1992 р. № 5/2-7-177. Київ, 1992. 8 с.

15. Містобудування. Планування і забудова населених пунктів. ДБН Б.2.2-1-01. URL : http://www. dnaop.com/html/34154/doc-ДБН_Б.2.4-2-94 (дата звернення 01.07.2020).

16. Михно М. В. Влияние состава транспортного потока на экологические показатели. Автошляховик Украӥни. 1999. № 3. С. 18.

17. Перельман А. И. Геохимия. Москва, 1989. 423 с.

18. Про планування і забудову територій : Закон України від 20 квітня 2000 p. № 1699-IП. URL : http://search.ligazakon.ua/l_doc2.nsf/link1/ T001699.html (дата звернення 05.07.2020).

19. Список стран по производству автотранспортных средств. URL : https://ru.qwe.wiki/wiki/List_of_countries_by_motor_vehicle_production.

20. Транспорт і зв'язок України за 2018 р. : стат. збірник / Держ. служба статистики України ; за ред. I. Петренко. URL : http://www.ukrstat.gov.ua/ druk/publicat/kat_u/2019/zb/08/zb_tr2018pdf.pdf (дата звернення 29.06.2020).

21. Хаустов $\bar{A}$. П. Геохимические барьеры с позиций синергетики (семантический анализ) / Геохимия ландшафтов (к 100-летию А. И. Перельмана). Доклад Всероссийской научной конференции, Москва, 18-20 октября 2016 г. Москва, 2016. С. 64-67.

22. Хаустов А. П. Геохимические барьеры как форма самоорганизации естественных геосистем. Вестник Российского университета дружбы народов. Серия «Экология и безопасность жизнедеятельности». 2017. T. 25. № 3. С. 396-413. DOI 10.22363/2313-2310-2017-25-3-396-413. 
23. Цвєткова Н. М., Тагунова Є. О. Геохімічні бар'єри в розподілі мангану в едафотопах Присамар'я Дніпровського. Visn. Dnipropetr. Univ. Ser. Biol. Ekol. 2015. 23(1). DOI:10.15421/011501.

24. Якубовский Ю. Автомобильный транспорт и защита окружающей среды. Москва, 1979. 198 с.

25. Kosheleva N., Vlasov D., Korlyakov I., Kasimov N. Effect of build development on contamination of urban soils with heavy metals. PNRPU. Applied ecology. Urban development. 2018. № 1. Pp. 36-55. DOI: 10.15593/2409-5125/2018.01.03.

\section{Information about author:}

Klymchyk O. M.,

Candidate of Agricultural Sciences, Associate Professor, Associate Professor at the Department of Ecological Safety and Environmental Economics

Polissya National University 7, Staryi blvd, Zhytomyr, 10008, Ukraine 